\title{
Determination In Vivo of Newly Synthesized Gene Expression in Hamsters During Phases of the Hibernation Cycle
}

\author{
P.G. OSBORNE, B. GAO, and M. HASHIMOTO \\ Department of Physiology, Asahikawa Medical University School of Medicine, Asahikawa, 078-8510 Japan
}

\begin{abstract}
This study measured in vivo synthesis of total RNA and protein from cortex, cerebellum and midbrain/brainstem and 6 major organs from Syrian hamsters (Mesocricetus auratus) during (a) $33 \mathrm{~h}$ of torpor (body temperature 5$6^{\circ} \mathrm{C}$ ); (b) 90 min of the early arousal; (c) 90 min of the middle arousal; (d) 90 min in cold adapted cenothermic (CEN) hamsters of the same circannual period. Appropriate physiological parameters were used to confirm the phase of the hibernation cycle during infusion and incorporation of $\left[{ }^{3} \mathrm{H}\right]-$ uridine and $\left[{ }^{14} \mathrm{C}\right]$-leucine. In torpor, RNA synthesis was $5-25 \%$ of CEN levels depending upon tissue. In brain and heart mRNA was not preferentially synthesized. Protein was synthesized at low, tissue specific levels during torpor. Initiation of arousal and the warming of anterior organs via
\end{abstract}

non-shivering thermogenesis during the early arousal occurred without measurable synthesis of RNA or proteins. Tissue specific levels of RNA and protein synthesis occurred later after shivering thermogenesis had been recruited and was strongly influenced by thermal gradients in the body. In the middle arousal phase, protein synthesis is most active in the brain despite modest synthesis of RNA and mRNA. The majority of molecular processing required for the induction and maintenance of torpor and the arousal from torpor up until the onset of shivering thermogenesis occurs during the cenothermic period before the hamster initiates the hibernation cycle. [The Japanese Journal of Physiology 54: 295-305, 2004]

Key words: transcription, protein synthesis, mRNA, torpor.

$\mathrm{H}_{\mathrm{i}}$ the hibernation season, the hibernation cycle of a 'classic' hibernator, such as the Syrian hamster, can be divided into six distinct physiological phases. An entrance phase, when metabolism is inhibited and body temperature decreases [1]. A long period of torpor when metabolic rate (MR) is approximately $2.5 \%$ of resting metabolic rate (RMR) [2, 3]. This is followed by an arousal period of three phases: an early arousal phase during which the animal warms anterior crucial organs by non-shivering thermogenesis; a middle arousal phase when shivering thermogenesis is recruited to heat the anterior body to cenothermia (CEN) and a late arousal phase when posterior organs attain CEN and the animal rests or sleeps. An inter-bout arousal phase, of hours to days, during which time the hibernator maintains CEN body temperature before the initiation of another hibernation cycle. At present the onset of the hibernation cycle cannot be predicted. (Cenothermia is the IUPS term replacing euthermia [4]).

Molecularly orientated studies have searched for up-or-down regulation of gene expression in a small number of organs from torpid animals in an attempt to demonstrate molecular changes that are consistent with the enormous physiological changes occurring across the hibernation cycle [5]. Early investigations used radioactively labeled precursors to measure in vivo transcription in brains $[6,7]$, translation in liver $[8,9]$, and more recently translation in brain and heart [10],

Received on March 3, 2004; accepted on June 7, 2004

Correspondence should be addressed to: Masaaki Hashimoto, Department of Physiology, Asahikawa Medical University School of Medicine, Asahikawa, 0768-8510 Japan. Tel: +81-166-68-2321, Fax: +81-166-68-2321, E-mail: mhashi@asahikawa-med.ac.jp 
indicated that during torpor transcription was greatly reduced and translation largely inhibited. The latter as a result of thermodynamic effects coincident with phosphorylation of initiation factor 2a [10, 11]. Ex vivo polysomal run-on analysis demonstrated that, in liver, elongation of pre-initiated peptides continues slowly during torpor although initiation of protein synthesis is inhibited [12]. It was also demonstrated that CEN polysomal profiles are re-established when a temperature of $18^{\circ} \mathrm{C}$ was surpassed [12]. A recent report [13] demonstrates in vitro protein synthesis (PS) in brown adipose tissue (BAT) from torpid squirrels. This suggests that inhibition of PS during torpor is not universally associated with low ambient temperature or phosphorylation of initiation factor $2 \mathrm{a}$ and raises the possibility of PS in vivo in other essential but as yet unexamined organs.

The control of transcription across the hibernation cycle is not well understood. An increasing number of studies have demonstrated decreased [14] or increased [13, 15-21] differential expression of cDNA probed levels of mRNA for a variety of genes, associated with biochemical adaptations considered relevant to hibernation, from tissues extracted at different phases of hibernation cycle. Although increased levels of mRNA in tissues from torpid animals appears to be consistent with earlier in vivo studies that demonstrate RNA transcription during torpor, the two procedures are not temporally complimentary.

In heart, brain and liver sufficient evidence is now available to indicate that in torpor, levels of total tissue RNA (as estimated from levels of ubiquitous RNA or mRNA) and protein, in the majority but not all organs examined [14], are not different from levels in CEN [10, 11, 13, 14, 19, 22, 23] while mRNA [24] and probably protein [25] are stabilized in torpor. The preservative character of torpor on the levels of genomic components determines that protein or mRNA levels in tissues harvested from animals in torpor will reflect both the molecular events active during torpor, and also a component residual to changes of synthesis or degradation that occurred prior to the initiation of torpor. Quantification of RNA and protein synthesized in vivo during specific phases of the hibernation cycle from labeled precursors provides a means to distinguishing between active gene expression and residual gene expression.

In an investigation of molecular processes that are active during different phases of the hibernation cycle, it is critical to monitor physiological parameters such as BAT temperature $\left(T_{\mathrm{BAT}}\right)$, heart rate $(\mathrm{HR})$ and respiratory rate (RespR) which when combined are reliable indicators of the phases of the hibernation cycle
[26]. Ambiguities arise when assigning the results of previous molecular studies to a specific phase of the hibernation cycle because the majority of researchers have favored the sole use of rectal or abdominal temperature $\left(T_{\text {RECTUM }}\right)$ to indicate that animals are in torpor. The rectal and abdominal regions are amongst the last tissues to be re-warmed during arousal [26] and as such $T_{\text {RECTUM }}$ is a good indicator of the middle arousal phase but unsuitable as an accurate bio-indicator of torpor.

The two previous studies of in vivo synthesis of total RNA during the phases of hibernation are physiologically problematic, are limited to analysis of cerebral tissue and do not examine the RNA being transcribed. In the earlier study on bats [7], intracerebroventricular injections of labeled orotoic acid was used as the precursor for de-novo pyrimidine synthesis. Under physiologic conditions, orotoic acid is a less appropriate substrate than uridine for cerebral RNA synthesis (RNAS) [27] since in most organs, except for liver and to some extent kidney, RNAS usually proceeds predominantly via the salvage pathway [28]. In the more recent study using torpid squirrels, it was demonstrated that intracerebroventricular injection of labeled uridine was incorporated into cerebral RNA at reduced rates relative to non-hibernating squirrels [6].

The aim of this study was to examine in vivo PS and RNAS, in Syrian hamsters (Mesocricetus auratus) in order to determine if the physiological phases of the hibernation cycle were associated with organ specific, distinct patterns of transcription and translation. We measured in vivo synthesis of total RNA and protein from the cortex, midbrain/brainstem and cerebellum and 6 major organs. We also measured mRNA synthesis in heart and midbrain/brainstem during torpor, during early arousal when non-shivering thermogenesis was maximal, during middle arousal when shivering thermogenesis had been recruited. These results were compared with the levels of in vivo mRNA synthesis in non-hibernating, cold adapted CEN hamsters of the same circannual period.

\section{MATERIALS AND METHODS}

Animals and housing. The following experiments conformed to the ethical guidelines of the Japanese Physiological Society and Asahikawa Medical University (ethics approval \# 02166). Male hamsters were housed at $22^{\circ} \mathrm{C}$ with $12: 12 \mathrm{~h}$ light dark cycle and $a d l i b$ food and water until 3 months of age or body weight (bwt) was greater than $120 \mathrm{~g}$. The hamsters were then housed individually, in constant darkness at $4^{\circ} \mathrm{C}$, with nest materials and $a d$ lib access 
to chow and water. An infrared motion sensor and copper/constantan thermocouple attached to each nest were used to monitor the duration of each hibernation bout. Hibernation in mature hamsters can be induced at any time of year after reducing ambient temperature to $5-10^{\circ} \mathrm{C}$ and housing in constant darkness for about 45 days. Once hibernation is initiated, hamsters will continue a regular hibernation cycle for about 10 weeks. Hamsters that had experienced 2-3 hibernation cycles were aroused and the femoral vein was cannulated after they had attained CEN.

Surgery and animal protocol. Using sterile surgical procedure, under Nembutal anesthesia $(45 \mathrm{mg} /$ kg bwt, IP, Dainippon seiyaku, Tokyo) supplemented with topical application of 4\% Xylocaine (Astra Zeneca, Osaka) to the skin wound, the femoral vein was cannulated so that the silicon tubing tip of a polyethelene cannula (PE-10, Becton Dickinson, Tokyo) was positioned in the inferior vena cava. The PE cannula was exteriorized between the shoulder blades and first filled with sterile glycerol and saline containing $200 \mathrm{IU}$ heparin (ratio 1:1). After surgery, the skin wound was irrigated with Xylocaine and the hamster was given a $5 \mathrm{ml} / \mathrm{kg}$ IP injection of sterile saline. Hamsters were returned to their home cage after recovery from anesthesia. Hamsters usually re-commenced hibernation within 7 days after surgery. Thirty to forty $h$ after the hamster had re-commenced hibernation the cannula was flushed and filled with sterile saline containing 5 IU of heparin and aroused from hibernation. Aroused hamsters usually re-hibernated within 2 days. Hamsters that did not re-hibernate within 1 week after surgery or flushing of cannula were allocated to the cold adapted, hibernation season cenothermic control group (CEN).

Phases of the hibernation cycle and in vivo infusion protocol for hamsters. The length of the hibernation cycle of hamster is $80-100 \mathrm{~h}$. Torpor lasts for approximately $70 \mathrm{~h}$ during which time the whole body MR of the hamster is approximately $2.5 \%$ of cenothermic cold adapted RMR [2, 3, 26]. In torpor, small changes in MR can be performed to defend the reduced body temperature against fluctuations in the low ambient temperature [29, 30]. Arousal from hibernation (rectal and brain temperature $4-5^{\circ} \mathrm{C}$ ) to CEN $\left(35-37^{\circ} \mathrm{C}\right)$ takes $3-3.5 \mathrm{~h}$ at an ambient temperature of $4^{\circ} \mathrm{C}$ and, on the basis of physiological parameters it can be divided into early, middle and late arousal phases. The early arousal is associated with a MR that increases from $2.5 \%$ to approximately $100 \%$ of RMR by non-shivering thermogenesis. RespR changes from Cheyne Stoke pattern and increases to the same rate as at resting CEN levels $[2,3,26]$. The middle arousal is associated with an increasing MR that peaks at 250 $300 \%$ of RMR after the recruitment of shivering thermogenesis $[2,3,26]$. At this time, BAT, cheek pouch and brain temperatures are near cenothermic. However, rectal and hindlimb temperatures remain low [3, $26,31]$ and the animal is incapable of coordinated walking. Late arousal is associated with warming of rectum to CEN, MR and RespR decrease to resting CEN levels $[2,3,26]$ and the animal rests or sleeps [32]. These phases are exemplified in Fig. 1 which is a composite of the physiological data from all animals used in this study.

In CEN animals, the chemical pathways for in vivo incorporation of uridine [27, 28, 33] and leucine [34] in particular have been well characterized. Previous in vivo studies have demonstrated that at $\mathrm{CEN}$, in vivo incubation periods of $30 \mathrm{~min}$ to $2 \mathrm{~h}$ are of suitable duration for quantifiable incorporation of radioactive precursors into RNA and PS and minimize degradation of newly synthesized molecules [27, 33, 34]. In regard to uridine incorporation, uridine is degraded in vivo in the liver but sufficient uridine escapes degradation to be incorporated into ribosomal and mRNA $[27,28,33]$. Unincorporated label and metabolites are removed by washing after extraction and subsequent chromatographic separations.

The length of the in vivo incubation periods for hamsters in torpor (31-36 h), early and middle arousal (90 min each) were chosen as the longest practical in vivo incubation periods that encompassed the physiology that characterizes each of these phases of hibernation. The duration of the early and middle arousal phases, is approximately 90 min however the duration of torpor is often approximately $60 \mathrm{~h}$ or double the in vivo incubation period. In vivo incubation periods of $60 \mathrm{~h}$ during torpor were attempted but proved not practical. Arguably, estimates of whole body oxygen consumption during the different in vivo incubation periods, rather than time per se, provides a physiological reference point from which amounts of protein or RNA synthesized may be related to the rate of synthesis at CEN. It should be recognized that the contributions of individual organs to whole body MR during torpor, early and middle arousal will be different than during CEN.

Radioactive uridine $\left[5,6-{ }^{3} \mathrm{H}\right]$ (specific activity: 30 $\mathrm{Ci} / \mathrm{mmol}$ ) and L-leucine $\left[1-{ }^{14} \mathrm{C}\right]$ (specific activity: 55 $\mathrm{mCi} / \mathrm{mmol}$ ) were purchased from (American Radiolabeled Chemicals Inc. Missouri, USA). Fourteen hamsters were allocated to one of 4 experimental groups. Cold adapted, circannual non-hibernating CEN hamsters $(n=4)$; hamsters in early arousal $(n=4)$; hamsters in middle arousal $(n=3)$; hamsters in the 
torpor $(n=3)$. Eleven hamsters were infused with uridine $\left[5,6-{ }^{3} \mathrm{H}\right] 50 \mu \mathrm{Ci} / 100 \mathrm{~g}$ bwt and L-leucine [1$\left.{ }^{14} \mathrm{C}\right] 10 \mu \mathrm{Ci} / 100 \mathrm{~g}$ bwt dissolved in $0.15 \mathrm{mls}$ of sterile saline. Two CEN and one early arousal hamsters were infused with only uridine $\left[5,6-{ }^{3} \mathrm{H}\right] 50 \mu \mathrm{Ci} / 100 \mathrm{~g}$ bwt dissolved in $0.15 \mathrm{ml}$ of sterile saline. Preliminary experiments were performed in two urethane anesthetized $\mathrm{CEN}$ hamsters infused with uridine $\left[5,6-{ }^{3} \mathrm{H}\right] 50 \mu \mathrm{Ci} /$ $100 \mathrm{~g}$ bwt and L-leucine $\left[1{ }^{14} \mathrm{C}\right] 10 \mu \mathrm{Ci} / 100 \mathrm{~g}$ bwt.

Experimental procedure and measurement of biophysical parameters. Hamsters in torpor for use in the early or middle arousal groups, were transferred to the dark room maintained at $4^{\circ} \mathrm{C}, 50$ to $60 \mathrm{~h}$ after commencing a cycle of hibernation. These animals were fitted with pre-calibrated rectal and BAT thermocouples. The skin above the interscapular BAT was anaesthetised with procaine, the interscapular BAT was acutely dissected through a small incision and a sterile, pre-calibrated thermocouple was secured between lobes of BAT with tissue glue. HR was recorded from stainless steel $27 \mathrm{G}$ needle electrodes acutely inserted into the skin on either side of the heart. These procedures initiated arousal. Thermocouples were connected to zero temperature reference refrigeration unit (Zero-con, Komatsu Electronics, Tokyo) and a thermocouple interface (IM-7, I-techno, Tokyo). HR was recorded on a biophysical amplifier (AVB-10, NihonKohden, Tokyo) connected to computer interfaces (Mac Lab 2e, ADInstruments, Sydney) and the data was stored electronically. An observer used a video camera coupled to an infrared light source to remotely monitor and count the RespR of hamsters.

Hamsters in the early arousal group were given an infusion of $150 \mu \mathrm{l}$ of radioactive uridine and leucine at $50 \mu \mathrm{l} / \mathrm{min}$ commencing as soon as the animal was instrumented. Ninety minutes later, before the onset of shivering thermogenesis, the animals were killed with an IV overdose of Nembutal. Hamsters in the middle arousal group were instrumented as above but the infusion of $150 \mu \mathrm{l}$ of radioactive uridine and leucine at $50 \mu \mathrm{l} / \mathrm{min}$ was delayed until both $T_{\mathrm{BAT}}$ reached $11^{\circ} \mathrm{C}$ and RespR was in excess of $35 \mathrm{~b} / \mathrm{min}$. Ninety minutes later, when the RespR was maximal the hamsters were killed with an overdose of Nembutal. The end of the EAP and the beginning of the MAP overlapped by approximately $25 \mathrm{~min}$. Hamsters in the torpor group were transferred to the experimental room and given an infusion of $150 \mu$ l of radioactive uridine and leucine at $5 \mu \mathrm{l} / \mathrm{min}$ commencing $18-20 \mathrm{~h}$ after the initiation of the torpor. Thirty-one to $36 \mathrm{~h}$ later the hamsters were killed with an IV overdose of Nembutal. Freely moving CEN hamsters were transferred to the dark and cold experimental room in their home cage and given an infusion of $150 \mu \mathrm{L}$ of radioactive uridine and leucine at $50 \mu \mathrm{L} / \mathrm{min}$. Ninety minutes later the animals were killed with an IV injection of Nembutal.

Tissue preparation and assay. Immediately before death, a blood sample was taken by cardiac puncture from the anesthetized hamster. Heart, liver, BAT, femoris muscle from the hind limb (FeM), rhomboid muscle from under interscapular BAT (RhM), kidney and brain were rapidly excised from dead hamsters. The brain was dissected into 4 parts: cerebellum, cerebral cortex, brainstem/midbrain (excluding olfactory bulb) and remainder including thalamus, septal and hippocampus. All tissues were immediately frozen in liquid nitrogen and then stored at $-80^{\circ} \mathrm{C}$ until assay. Urine in the bladder was collected. Radioactivity in plasma and urine was measured. Tissues were weighted (approx. $140 \mathrm{mg}$ used for each determination) and pulverized frozen, homogenized in Tryzol solution (Life Technologies, USA) and the RNA and protein were separated as per manufacturers procedure. Total RNA was washed extensively in $80 \%$ ethanol before non-incorporated radioactive nucleotides and RNA $<20$ bases long were removed by size exclusion chromatography (MiniQuick spin RNA column, Roche, USA). In brain and heart, mRNA was separated from approximately $150 \mu \mathrm{g}$ of total RNA using poly dT affinity chromatography (Oligotex-dt30, Takara, Japan). RNA and mRNA were quantified by measurement of absorbance at $260 \mathrm{~nm}$ and purity of sample was estimated by the ratio of absorbance 260/ 280 nm using Gene Quant II (Pharmacea Biotech, UK). Aqueous solutions of RNA and mRNA were added to a scintillation fluid containing toluene/triton $\mathrm{X}$ (ratio 2:1), $10 \%$ water and 2,5 Diphenyloxazole (0.5\%). Protein extracted from tissue was dissolved in $1 \%$ SDS. Total tissue protein concentration was determined using protein assay kit that measured absorbance at 562 nm (Pierce, USA). A known quantity of tissue protein (1500-1800 $\mu \mathrm{g}$ ) was precipitated from solution using $7 \%$ TCA and applied to $45 \mu \mathrm{m}$ nitrocellulose filter paper (Millipore, Ireland). The precipitated protein was washed copiously with 5\% TCA solution. Filter papers were dried at $70^{\circ} \mathrm{C}$ for $90 \mathrm{~min}$ and applied to an aqueous free scintillation fluid (Atomlight, Perkin Elmer, Tokyo). Since only $2 \mathrm{CEN}$ animals received $\left[{ }^{14} \mathrm{C}\right]$-leucine infusions, protein determinations were performed twice from 2 separate tissue extractions from all animals for all tissues except the cerebellum and cerebral cortex. These two tissues were insufficient for repeated extraction. $\left[{ }^{3} \mathrm{H}\right]$ emissions from RNA solutions and $\left[{ }^{14} \mathrm{C}\right]$ emissions from protein impregnated filters were measured using scintillation counter 
(LS6500 Beckman USA). $\left[{ }^{3} \mathrm{H}\right]$ and $\left[{ }^{14} \mathrm{C}\right]$ emissions were counted in channels $0-400$ and 400-670 respectively. Total radioactivity was counted in channels 0 670. Chromatographic separation of RNA from protein and the high concentration of $\left[{ }^{3} \mathrm{H}\right]$ administered relative to $\left[{ }^{14} \mathrm{C}\right]$ determined that the contribution of $\left[{ }^{14} \mathrm{C}\right]$ to the tritium channels was minimal. In the 2 CEN and 1 early arousal animals tested, tissue levels of incorporation of $\left[{ }^{3} \mathrm{H}\right]$ in RNA were not different between animals injected only with $\left[5,6-{ }^{3} \mathrm{H}\right]$ uridine and those injected with both $\left[5,6-{ }^{3} \mathrm{H}\right]$ uridine and $\left[{ }^{14} \mathrm{C}\right]-$ leucine. DNA was extracted from cerebral tissue by digestion and purified using affinity chromatography (DNeasy Kit, Qiagen, Japan). The DNA was quantified by fluorometry (excitation $380 \mathrm{~nm}$, emission $460 \mathrm{~nm}$ ) after reaction of DNA with Hoechst 33258 fluorochrome (BioRad, USA) and comparison against calf thymus DNA.

\section{RESULTS}

Figure 1 shows the average $T_{\mathrm{BAT}}$ and $T_{\mathrm{RECTAL}}$, RespR profile of hamsters from the 4 in vivo incubation periods. Continuous torpor was confirmed by data from a motion sensor and nest thermocouple, and Cheyne Stoke respiratory pattern, HR of $13 \pm 1 \mathrm{~b} / \mathrm{min}(n=3 \mathrm{ham}-$ sters) and $T_{\text {RECTUM }}$ of $5-6^{\circ} \mathrm{C}$ immediately before sacrifice after 30-36 h of in vivo incubation. On the basis

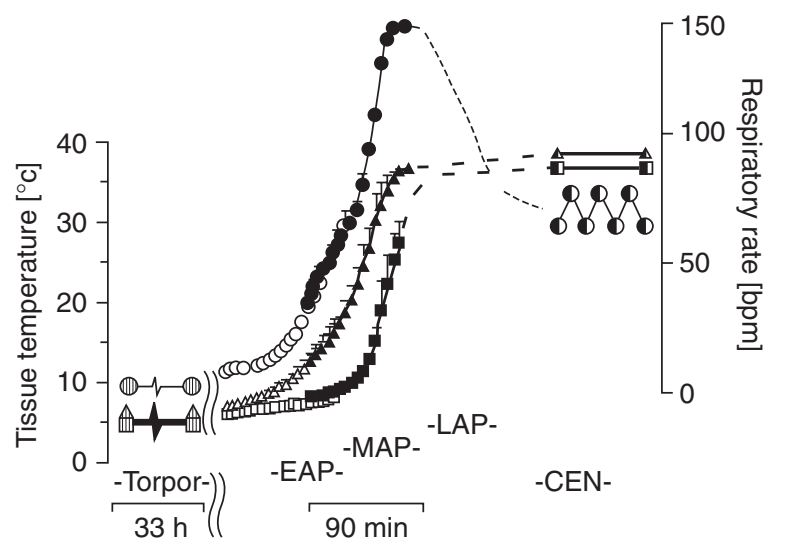

Fig. 1. Averaged physiological profile of all hamsters during in vivo incorporation of $\left[{ }^{3} \mathrm{H}\right]$-uridine and $\left[{ }^{14} \mathrm{C}\right]$ leucine. $T_{\mathrm{BAT}}{ }^{\circ} \mathrm{C}$ - triangles, $T_{\text {RECTUM }}{ }^{\circ} \mathrm{C}$ - squares, Respiratory rate (breaths/min) - circles (Mean \pm SEM). Torpor incubation in 3 hamsters was $33 \pm 1$ h (striped symbols). Early arousal phase (EAP) incubation in 4 hamsters was 90 min (open symbols). Middle arousal phase (MAP) incubation in 3 hamsters was 90 min (filled symbols). CEN incubation in 4 hamsters was $90 \mathrm{~min}$ (half filled symbols). Time course of physiological changes in late arousal phase (LAP, not measured in this experiment) are shown as dotted lines and are estimated from a previous publication by the present authors [26]. of whole body MR, $60 \mathrm{~h}$ of torpor is metabolically equivalent to 90 min of cold adapted CEN, assuming MR during torpor is $2.5 \%$ RMR during cold adapted CEN $[2,3,26]$. Thus the metabolic expenditure over $33 \mathrm{~h}$ of torpor is approximately 50\% of RMR over 90 min at cold adapted CEN.

In 4 hamsters at the beginning of the early arousal phase, $T_{\text {BAT }}$ and $T_{\text {RECTAL were }} 6.3 \pm 0.1$ and $5.5 \pm$ $0.1^{\circ} \mathrm{C}$ respectively. RespR and HR were $2 \pm 1 \mathrm{~b} / \mathrm{min}$ and $18 \pm 2 \mathrm{~b} / \mathrm{min}$ respectively. At the end of the early arousal period $T_{\mathrm{BAT}}$ and $T_{\mathrm{RECTAL}}$ were $17.6 \pm 1.0$ and $7.7 \pm 0.5^{\circ} \mathrm{C}$ respectively. RespR and HR were $71 \pm 5$ $\mathrm{b} / \mathrm{min}$ and $112 \pm 13 \mathrm{~b} / \mathrm{min}$, respectively. The oxygen consumption over $90 \mathrm{~min}$ of early arousal was estimated to be approximately $40 \%$ of oxygen consumption over $90 \mathrm{~min}$ at cold adapted CEN. This was estimated by comparing the increase of RespR and $T_{\mathrm{BAT}}$ in these experimental hamsters with the increase RespR, $T_{\mathrm{BAT}}$ and oxygen consumption in 4 other hamsters arousing at the same ambient temperature over the same time period [26].

Middle arousal phase began when RespR, HR and $T_{\mathrm{BAT}}$ were $39 \pm 3 \mathrm{~b} / \mathrm{min}$ and $46 \pm 3 \mathrm{~b} / \mathrm{min}$ and $11^{\circ} \mathrm{C}$, respectively. This phase was completed 90 min later, just prior to the animals becoming ambulatory, when RespR was maximal $(150 \mathrm{~b} / \mathrm{min})$ and $T_{\mathrm{BAT}}$ was $36^{\circ} \mathrm{C}$. As with animals in early arousal phase, the metabolic expenditure during this 90 min was estimated by matching the increase in RespR and $T_{\mathrm{BAT}}$ with previously published measurements of oxygen consumption [26]. The oxygen consumption over 90 min of early arousal phase was estimated to be approximately $150 \%$ of RMR over 90 min at cold adapted CEN. CEN animals were not instrumented and slept or displayed low level activity with RespR of 60-70 b/min during the $90 \mathrm{~min}$ in vivo incubation period.

Table 1 shows that after the in vivo incubation periods, plasma levels of $\left[{ }^{14} \mathrm{C}\right]$-leucine were greatest in hamsters of the early arousal, intermediate in torpor and CEN and lowest in middle arousal $(P<0.05)$. Plasma levels of $\left[{ }^{3} \mathrm{H}\right]$-uridine were lowest in middle arousal and not different in other phases $(P<0.05)$. Plasma $\left[{ }^{14} \mathrm{C}\right]$-radioactivity for $4 \mathrm{CEN}$ animals is derived from 2 conscious CEN hamsters and 2 urethane anesthetized CEN hamsters. Total radioactive loss to urine was very low in torpor, early and middle arousal, and greatest during CEN when kidney function was normal. Uptake of radioactive substances by red blood cells during any phase of hibernation was not detectable.

Table 2 shows that total RNA and protein content were different between tissues. The extraction efficiency of RNA or protein from the same organ was 
P.G. OSBORNE et al.

Table 1. Physiological parameters of hamsters during in vivo incorporation of $\left[{ }^{3} \mathrm{H}\right]$-uridine and $\left[{ }^{14} \mathrm{C}\right]$-leucine.

\begin{tabular}{cccccccc}
\hline $\begin{array}{c}\text { Hibernation } \\
\text { phase }\end{array}$ & $\begin{array}{c}\text { BWT } \\
{[\mathrm{g}]}\end{array}$ & $\begin{array}{c}\text { BAT } \\
\text { Temp } \\
{\left[{ }^{\circ} \mathrm{C}\right]}\end{array}$ & $\begin{array}{c}\text { RespR } \\
{[\mathrm{b} / \mathrm{min}]}\end{array}$ & $\begin{array}{c}\text { Urine } \\
\text { volume } \\
{[\mathrm{ml}]}\end{array}$ & $\begin{array}{c}\text { Urine } \\
\text { activity } \\
{[\mathrm{cts} / \mathrm{min} / 60 \mu \mathrm{l}]}\end{array}$ & $\begin{array}{c}\left.{ }^{14} \mathrm{C}\right] \text {-Plasma } \\
\text { activity } \\
{[\mathrm{cts} / \mathrm{min} / 60 \mu \mathrm{l}]}\end{array}$ & $\begin{array}{c}{\left[{ }^{3} \mathrm{H}\right] \text {-Plasma }} \\
\text { activity } \\
{[\mathrm{cts} / \mathrm{min} / 60 \mu \mathrm{l}]}\end{array}$ \\
\hline $\begin{array}{c}\mathrm{CEN} \\
n=4^{*}\end{array}$ & $127 \pm 5^{\mathrm{b}, \mathrm{c}}$ & $36-37$ & $60-70$ & $0.65 \pm 0.2^{\mathrm{b}, \mathrm{c}}$ & $306976 \pm 71510^{\mathrm{b}, \mathrm{c}}$ & $7832 \pm 1432^{* \mathrm{~b}}$ & $8724 \pm 1068$ \\
$\begin{array}{c}\text { Middle } \\
\text { arouse } \\
n=3\end{array}$ & $101 \pm 4^{\mathrm{a}}$ & $11-36$ & $39-153$ & $0.2 \pm 0.1^{\mathrm{a}}$ & $9039 \pm 2290^{\mathrm{a}}$ & $5274 \pm 958^{\mathrm{b}}$ & $3911 \pm 1674$ \\
$\begin{array}{c}\text { Early arouse } \\
n=4 \\
\begin{array}{c}\text { Torpor } \\
n=3\end{array}\end{array}$ & $108 \pm 5^{\mathrm{a}}$ & $5-18$ & $2-71$ & $0.1 \pm 0.05^{\mathrm{a}}$ & $4315 \pm 2150^{\mathrm{a}}$ & $18117 \pm 1330^{\mathrm{a}, \mathrm{c}}$ & $5927 \pm 404$ \\
\hline
\end{tabular}

$\left[{ }^{3} \mathrm{H}\right]$-plasma counts $-F(3,13)=6.5, P=0.01 ;\left[{ }^{14} \mathrm{C}\right]$-plasma counts $-F(3,12)=16.2, P=0.0006$; Urine total counts $-F(3,13)$ $=12.3, P=0.0015$; Urine volume $-F(3,13)=4.6, P=0.03$; BWT $-F(3,13)=4.9, P=0.02$. a - diff from CEN $p<0.05$; $\mathrm{b}$ - diff from early arousal $p<0.05$; $\mathrm{c}$ - diff from middle arousal hamsters. ${ }^{*}\left[{ }^{14} \mathrm{C}\right]$-Plasma activity includes $\left[{ }^{14} \mathrm{C}\right]$-plasma activity from 2 urethane anesthetised CEN animals. Mean \pm SEM or range of the values are shown in this and following tables.

not different between phases of hibernation. For every RNA extraction $260 / 280 \mathrm{~nm}$ absorbance ratio was $>1.74$. In all tissues, incorporation of $\left[{ }^{3} \mathrm{H}\right]$-uridine into total RNA was greatest in CEN, invariably below the detection limit in early arousal and intermediate in torpor. Incorporation during middle arousal phase was consistent within animals but extremely variable as a group, with one animal having levels greater than CEN. In FeM, $\left[{ }^{3} \mathrm{H}\right]$-uridine and $\left[{ }^{14} \mathrm{C}\right]$-leucine incorporation remained undetectable in middle arousal. Incorporation of $\left[{ }^{14} \mathrm{C}\right]$-leucine into protein was below the detection limit in early arousal and low during torpor. The amount of $\left[{ }^{14} \mathrm{C}\right]$-leucine incorporation during middle arousal was tissue specific ranging from no incorporation in FeM while in cerebellum and brain stem/mid brain incorporation was not different from CEN.

Comparison of total RNA content of brain (pooling all brain areas) or peripheral tissues (pooling all tissues) from CEN hamsters and hamsters in torpor, as determined from RNA extracted per mg of wet tissue, indicates that brain tissue from hibernating animals has more RNA/mg tissue than CEN hamsters (Torpor $-0.91 \pm 0.041 \mu \mathrm{g}$ RNA/mg tissue $(n=12)$; CEN $0.79 \pm 0.035 \mu \mathrm{g}$ RNA/mg tissue $(n=16)$, Mann Whitney $U=47, P>0.05$ ). If hamsters in early arousal were included with torpid hamsters this significant difference was retained $(0.89 \pm 0.033 \mu \mathrm{g} \mathrm{RNA} / \mathrm{mg}$ cerebral tissue $(n=21)$. The DNA content of brain tissue was not different between torpor $(0.81 \pm 0.08 \mu \mathrm{g} / \mathrm{mg}, n=$ $11)$ and CEN hamsters $(0.77 \pm 0.08 \mu \mathrm{g} / \mathrm{mg}, n=15)$. There was no difference in the amount of RNA/mg tissue in peripheral organs between torpid $(1.44 \pm 0.16$ $\mu \mathrm{g} / \mathrm{mg}, n=39)$ and CEN hamsters $(1.46 \pm 0.2 \mu \mathrm{g} / \mathrm{mg}$, $n=22$ ).

Figure 2 shows a linear relationship ( $y=0.036 x-$
0.064. $\left.r^{2}=0.937\right)$ in the amount of $\left[{ }^{14} \mathrm{C}\right]$-leucine incorporated into protein in the 9 tissues between CEN and torpor. Incorporation of $\left[{ }^{14} \mathrm{C}\right]$-leucine into $\mathrm{FeM}$ during torpor was not detectable. The relationship in the amount of $\left[{ }^{3} \mathrm{H}\right]$-uridine incorporated into total RNA in tissues between CEN and torpor is not significant if all tissues were included in a linear analysis. However a significant relationship $\left(y=0.041 x+0.469 \cdot r^{2}=\right.$ 0.98 ) was found when heart and kidney tissue were excluded from the analysis.

Table 3 shows the incorporation of $\left[{ }^{3} \mathrm{H}\right]$-uridine into RNA and mRNA from heart and mid brain/brain stem during CEN, middle arousal and torpor. Total RNA for mRNA purification is derived from a separate tissue extraction from data present in Table 2. Total RNA and mRNA contents were different between tissues, however the extraction efficiency of total RNA or mRNA was not different between phases within the same tissue. Incorporation of $\left[{ }^{3} \mathrm{H}\right]$-uridine into total RNA was consistent with extractions in Table 2. $\left[{ }^{3} \mathrm{H}\right]-$ uridine was preferentially incorporated into mRNA in CEN. Incorporation of $\left[{ }^{3} \mathrm{H}\right]$-uridine into mRNA is greatest in CEN and middle arousal. Incorporation during middle arousal was variable between hamsters. In torpor, incorporation of $\left[{ }^{3} \mathrm{H}\right]$-uridine into mRNA was low in both tissues. According to manufacturer's specifications, retention of $\left[{ }^{3} \mathrm{H}\right]$-uridine labeled non-mRNA containing a high concentration of adenosine nucleotides during purification chromatography probably contributes to $10 \%$ of $\left[{ }^{3} \mathrm{H}\right]$-uridine signal attributed to mRNA. This contribution to $\left[{ }^{3} \mathrm{H}\right]-$ mRNA signal is small for CEN and large for torpor.

Analysis and presentation of data. Raw physiological data were analyzed by one way ANOVA with Tukey correction for multiple comparisons. In com- 
Gene Expression during Hibernation

Table 2. Incorporation of $\left[{ }^{3} \mathrm{H}\right]$-uridine and $\left[{ }^{14} \mathrm{C}\right]$-leucine into RNA and protein in organs during phases of the hibernation cycle.

\begin{tabular}{|c|c|c|c|c|c|c|c|c|c|c|}
\hline & & Heart & Liver & BAT & FeM & RhM & Kidney & $\begin{array}{l}\text { Cereb- } \\
\text { ellum }\end{array}$ & Cortex* & $\begin{array}{l}\text { Brain } \\
\text { stem }\end{array}$ \\
\hline $\begin{array}{l}\text { NA } \\
\text { tract }\end{array}$ & $\underset{(n)}{\mu \mathrm{g} / \mathrm{mg}}$ & $\begin{array}{l}0.96 \pm \\
0.03 \\
(13)\end{array}$ & $\begin{array}{c}3.55 \pm 0.11 \\
\quad(13)\end{array}$ & $\begin{array}{c}1.3 \pm 0.06 \\
(13)\end{array}$ & $\begin{array}{c}0.56 \pm 0.03 \\
(13)\end{array}$ & $\begin{array}{l}0.66 \pm \\
0.03 \\
(13)\end{array}$ & $\begin{array}{l}2.15 \pm \\
0.06 \\
(12)\end{array}$ & $\begin{array}{l}1.03 \pm \\
0.03 \\
(13)\end{array}$ & $\begin{array}{l}0.92 \pm \\
0.03 \\
(13)\end{array}$ & $\begin{array}{l}0.75 \pm \\
0.03 \\
(13)\end{array}$ \\
\hline $\begin{array}{l}\text { Protein } \\
\text { extract }\end{array}$ & $\begin{array}{c}\mu \mathrm{g} / \mathrm{mg} \\
(n)\end{array}$ & $\begin{array}{c}28 \pm 2 \\
(22)\end{array}$ & $\begin{array}{c}52 \pm 2 \\
(22)\end{array}$ & $\begin{array}{c}44 \pm 4 \\
(22)\end{array}$ & $\begin{array}{c}14 \pm 1 \\
(22)\end{array}$ & $\begin{array}{c}17 \pm 1 \\
(22)\end{array}$ & $\begin{array}{c}33 \pm 2 \\
(22)\end{array}$ & $\begin{array}{c}24 \pm 1 \\
(22)\end{array}$ & $\begin{array}{c}17 \pm 1 \\
(22)\end{array}$ & $\begin{array}{l}22 \pm 2 \\
(22)\end{array}$ \\
\hline \multirow[t]{3}{*}{ CEN } & $\begin{array}{c}\text { RNA } \\
{ }^{3} \mathrm{H} \text { cts } / \mu \mathrm{g}\end{array}$ & $\begin{array}{c}19.8 \pm 3.7 \\
(4)\end{array}$ & $\begin{array}{l}2.6 \pm 0.6 \\
(4)\end{array}$ & $\begin{array}{c}33.8 \pm 7.7 \\
\text { (4) }\end{array}$ & $\begin{array}{c}10.8 \pm 3.4 \\
(4)\end{array}$ & $\begin{array}{c}11.1 \pm 3.5 \\
(4)\end{array}$ & $\begin{array}{c}21.1 \pm 4.7 \\
(4)\end{array}$ & $\begin{array}{c}4.0 \pm 1.2 \\
(4)\end{array}$ & $\begin{array}{l}2.4 \pm 0.7 \\
(4)\end{array}$ & $\begin{array}{l}2.2 \pm 0.6 \\
(4)\end{array}$ \\
\hline & $\%$ of CEN & [100] & [100] & [100] & [100] & [100] & [100] & [100] & [100] & {$[100]$} \\
\hline & $\begin{array}{l}\text { Protein } \\
{ }^{14} \mathrm{C} \text { cts } / \mu \mathrm{g} \\
\% \text { of CEN }\end{array}$ & $\begin{array}{c}0.39 \pm \\
0.03 \\
(4) \\
{[100]}\end{array}$ & $\begin{array}{c}0.97 \pm 0.04 \\
(4) \\
{[100]}\end{array}$ & $\begin{array}{c}0.41 \pm \\
0.01 \\
(4) \\
{[100]}\end{array}$ & $\begin{array}{c}0.11 \pm \\
0.01 \\
(4) \\
{[100]}\end{array}$ & $\begin{array}{c}0.22 \pm \\
0.02 \\
(4) \\
{[100]}\end{array}$ & $\begin{array}{c}1.16 \pm \\
0.07 \\
(4) \\
{[100]}\end{array}$ & $\begin{array}{c}0.31 \\
(2) \\
{[100]}\end{array}$ & $\begin{array}{c}0.45 \\
(2) \\
\\
{[100]}\end{array}$ & $\begin{array}{c}0.34 \pm \\
0.01 \\
(4) \\
{[100]}\end{array}$ \\
\hline \multirow[t]{3}{*}{$\begin{array}{l}\text { Middle } \\
\text { arousal }\end{array}$} & $\begin{array}{c}\text { RNA } \\
(n)\end{array}$ & $\begin{array}{c}27.2 \pm 18.9 \\
\text { (3) }\end{array}$ & $\begin{array}{c}0.2 \pm 0.1 \\
(3)^{\mathrm{a}}\end{array}$ & $\begin{array}{c}7.1 \pm 4.9 \\
\text { (3) }\end{array}$ & $\begin{array}{l}0.2 \pm 0 \\
(3)^{\mathrm{a}}\end{array}$ & $\begin{array}{c}8.1 \pm 5.8 \\
(3)\end{array}$ & $\begin{array}{c}2.5 \pm 1.9 \\
(3)\end{array}$ & $\begin{array}{c}1.3 \pm 0.9 \\
(3)\end{array}$ & $\begin{array}{c}1.1 \pm 0.8 \\
(3)\end{array}$ & $\begin{array}{c}1.2 \pm 0.7 \\
(3)\end{array}$ \\
\hline & $\%$ of CEN & [138] & [7] & [21] & [1] & [72] & [12] & [31] & [45] & [53] \\
\hline & $\begin{array}{l}\text { Protein } \\
\qquad(n) \\
\text { \% of CEN }\end{array}$ & $\begin{array}{c}0.22 \pm \\
0.03 \\
(6)^{\mathrm{a}} \\
{[55]}\end{array}$ & $\begin{array}{l}0.32 \pm \\
0.08 \\
(6)^{\mathrm{a}} \\
{[33]}\end{array}$ & $\begin{array}{c}0.19 \pm \\
0.01 \\
(6)^{a} \\
{[47]}\end{array}$ & $\begin{array}{c}0.00 \pm 0 \\
(6)^{a} \\
{[0]}\end{array}$ & $\begin{array}{l}0.13 \pm \\
0.02 \\
(6)^{a} \\
{[59]}\end{array}$ & $\begin{array}{c}0.26 \pm \\
0.02 \\
(6)^{a} \\
{[22]}\end{array}$ & $\begin{array}{c}0.32 \pm \\
0.03 \\
(3) \\
{[105]}\end{array}$ & $\begin{array}{c}0.38 \pm \\
0.03 \\
(3) \\
{[83]}\end{array}$ & $\begin{array}{c}0.36 \pm \\
0.02 \\
(6) \\
{[106]}\end{array}$ \\
\hline \multirow[t]{3}{*}{$\begin{array}{l}\text { Early } \\
\text { arousal }\end{array}$} & $\begin{array}{c}\text { RNA } \\
(n)\end{array}$ & $\begin{array}{l}0.4 \pm 0 \\
(4)^{\mathrm{a}}\end{array}$ & $\begin{array}{l}0 \pm 0 \\
(4)^{a}\end{array}$ & $\begin{array}{l}0.2 \pm 0 \\
(4)^{\mathrm{a}}\end{array}$ & $\begin{array}{l}0.1 \pm 0 \\
(4)^{\mathrm{a}}\end{array}$ & $\begin{array}{l}0 \pm 0 \\
(4)^{a}\end{array}$ & $\begin{array}{l}0.1 \pm 0 \\
(4)^{\mathrm{a}}\end{array}$ & $\begin{array}{c}0.1 \pm 0 \\
(4)^{\mathrm{a}}\end{array}$ & $\begin{array}{l}0 \pm 0 \\
(4)^{a}\end{array}$ & $\begin{array}{l}0.1 \pm 0 \\
(4)^{\mathrm{a}}\end{array}$ \\
\hline & $\%$ of CEN & [2] & [2] & [1] & [1] & [0] & [0] & [2] & [0] & [2] \\
\hline & $\begin{array}{l}\text { Protein } \\
(n) \\
\% \text { of CEN }\end{array}$ & $\begin{array}{l}0 \pm 0 \\
(6)^{\mathrm{a}} \\
{[1]}\end{array}$ & $\begin{array}{l}0 \pm 0 \\
(6)^{\mathrm{a}} \\
{[0]}\end{array}$ & $\begin{array}{l}0 \pm 0 \\
(6)^{\mathrm{a}} \\
{[1]}\end{array}$ & $\begin{array}{l}0 \pm 0 \\
(6)^{\mathrm{a}} \\
{[0]}\end{array}$ & $\begin{array}{l}0 \pm 0 \\
(6)^{\mathrm{a}} \\
{[0]}\end{array}$ & $\begin{array}{l}0 \pm 0 \\
(6)^{\mathrm{a}} \\
{[0]}\end{array}$ & $\begin{array}{c}0.01 \pm 0 \\
(3)^{\mathrm{a}} \\
{[2]}\end{array}$ & $\begin{array}{c}0.01 \pm 0 \\
(3)^{\mathrm{a}} \\
{[1]}\end{array}$ & $\begin{array}{l}0 \pm 0 \\
(6)^{\mathrm{a}} \\
{[1]}\end{array}$ \\
\hline \multirow[t]{3}{*}{ Torpor } & $\begin{array}{l}\text { RNA } \\
(n)\end{array}$ & $\begin{array}{l}4.1 \pm 0.2 \\
(3)\end{array}$ & $\begin{array}{c}0.7 \pm 0.1 \\
(3)\end{array}$ & $\begin{array}{c}1.9 \pm 0.3 \\
(3)\end{array}$ & $\begin{array}{c}0.9 \pm 0.1 \\
(3)\end{array}$ & $\begin{array}{c}0.9 \pm 0.2 \\
(3)\end{array}$ & $\begin{array}{c}3.8 \pm 1.3 \\
(3)\end{array}$ & $\begin{array}{c}0.6 \pm 0.1 \\
(3)\end{array}$ & $\begin{array}{c}0.6 \pm 0.0 \\
(3)\end{array}$ & $\begin{array}{c}0.6 \pm 0.1 \\
(3)\end{array}$ \\
\hline & $\%$ of CEN & [20] & [25] & [6] & [8] & [8] & [19] & [14] & [26] & [26] \\
\hline & $\begin{array}{l}\text { Protein } \\
\quad(n) \\
\% \text { of CEN }\end{array}$ & $\begin{array}{c}0.01 \pm 0 \\
(6)^{\mathrm{a}} \\
{[3]}\end{array}$ & $\begin{array}{c}0.04 \pm 0.0 \\
(6)^{\mathrm{a}} \\
{[4]}\end{array}$ & $\begin{array}{c}0.02 \pm 0 \\
(6)^{\mathrm{a}} \\
{[5]}\end{array}$ & $\begin{array}{l}0 \pm 0 \\
(6)^{\mathrm{a}} \\
{[0]}\end{array}$ & $\begin{array}{c}0.00 \pm 0 \\
(6)^{\mathrm{a}} \\
{[1]}\end{array}$ & $\begin{array}{c}0.03 \pm 0.01 \\
(6)^{\mathrm{a}} \\
{[3]}\end{array}$ & $\begin{array}{c}0.01 \pm 0 \\
(3)^{\mathrm{a}} \\
{[2]}\end{array}$ & $\begin{array}{c}0.02 \pm 0 \\
(3)^{\mathrm{a}} \\
{[4]}\end{array}$ & $\begin{array}{c}0.01 \pm 0 \\
(6)^{\mathrm{a}} \\
{[2]}\end{array}$ \\
\hline
\end{tabular}

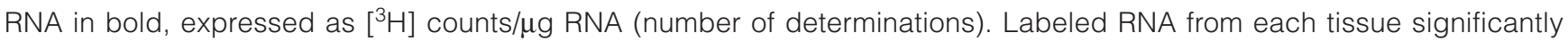
different between phases of hibernation $-\mathrm{KW}>8.7 ; P>0.01$ for all. Within same tissue early arousal phase different from others $p>0.05$, except FeM during middle arousal phase. Protein in plain font, expressed as $\left[{ }^{14} \mathrm{C}\right] \mathrm{cts} / \mu \mathrm{g}$ protein (number of determinations). Labeled protein from each tissue significantly different between phases of hibernation $-\mathrm{KW}>16.7$; $P>0.001$ for all. Within same tissue a - different from CEN $p>0.05 \%$ of CEN - mean incorporation into tissue during phase of hibernation expressed as \% of mean incorporation of same tissue during CEN. * tissue assayed for protein incorporation only once. Other tissues assayed twice from separate extractions.

parison of RNAS and PS in phases of hibernation, data were analyzed by either Mann Whitney test for 2 groups or Kruskal-Wallis nonparametric ANOVA with Dunn's correction for multiple comparisons. Means \pm SEM. $(n) . P<0.05$ two tailed significance.

\section{DISCUSSION}

In CEN hamsters, the relative amount of PS and RNAS expectedly varied between organs while the low rate of RNAS synthesis in the liver is consistent with the dominance of de-novo synthesis in this organ [28]. In regard to in vivo PS and RNAS during torpor, the results of the present study are in good agreement with previous in vivo PS [8-10] and in vivo RNAS studies [6,7]. The additional organs assayed in this study provide a more complete picture of PS and RNAS during torpor and the other phases of the hibernation cycle. Labeled leucine was transported from the blood and translation occurred at tissue specific, reduced 


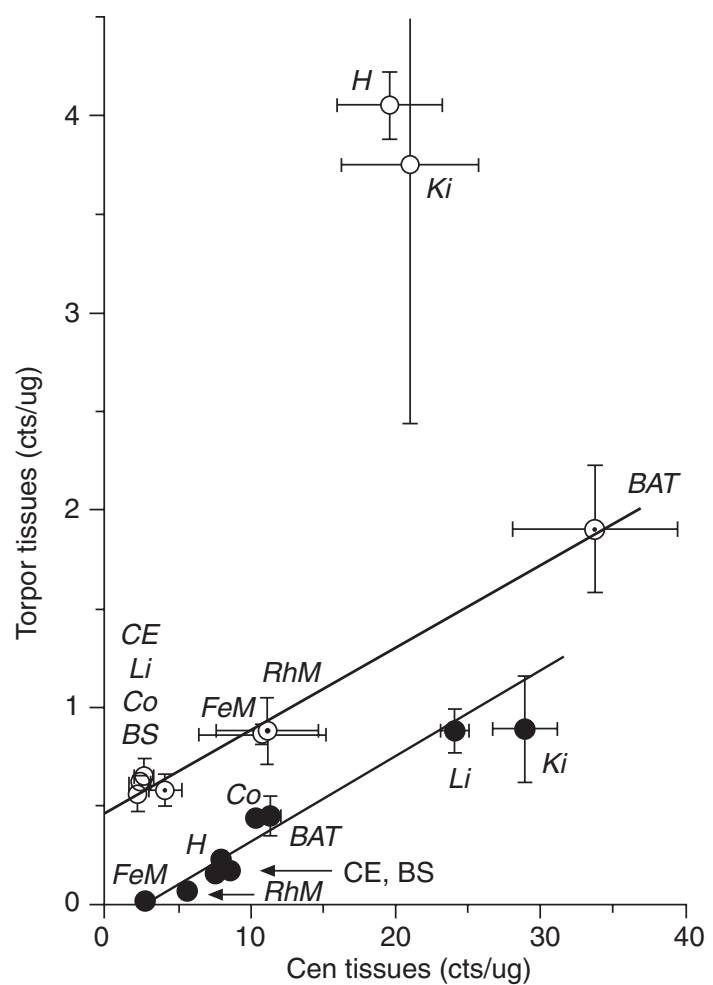

Fig. 2. The relationship between incorporation of $\left[{ }^{14} \mathrm{C}\right]-$ leucine into protein $\left(\left[{ }^{14} \mathrm{C}\right]\right.$-cts/ $\left.\mu \mathrm{g}\right)$ and $\left[{ }^{3} \mathrm{H}\right]$-uridine into total $\operatorname{RNA}\left(\left[{ }^{3} \mathrm{H}\right]\right.$-cts/ $\left.\mu \mathrm{g}\right)$ in 9 tissues during CEN and torpor. Filled circles - protein, tissue in bold script. Open circles - Total RNA, tissue in italic script. In order to accommodate both data sets on the same graph the data for protein incorporation has been multiplied by 25. Mean \pm SEM for each tissue ( $n=4$ for CEN; $n=3$ for torpor). Linear regression for $\left[{ }^{14} \mathrm{C}\right]$ leucine incorporation into protein for 9 tissues $y=0.036 x-$ 0.064. $R^{2}=0.936$. Linear regression for $\left[{ }^{3} \mathrm{H}\right]$-uridine incorporation into RNA for 7 tissues $y=0.041 x-0.469$. $R^{2}=$ 0.987 . (Heart and kidney excluded from RNA regression). $\mathrm{H}$ - heart, Li - liver, Ki - kidney, BAT - brown adipose tissue, FeM - femoris muscle from hindlimb, RhM - Rhomboid muscle from under interscapular BAT, Co - cortex, BS - brain stem/ mid brain, $\mathrm{Ce}$ - cerebellum.

amounts relative to CEN in all organs assayed during torpor. In each organ assayed, the amount of PS during torpor is greatly reduced but directly related to the amount of PS during CEN. This implies a mechanism of inhibition common to all tissues carried over from CEN and is consistent with continued elongation of pre-initiated polypeptides after PS had been inhibited during torpor, as has been demonstrated ex vivo in liver polysomes [12]. In contrast to in vitro analysis of ground squirrel BAT [13], PS in vivo in hamster BAT was not increased relative to other tissues. In the hamsters, it would appear that none of the organs examined synthesized large quantities of protein at low body temperatures of torpor.

In general, the level of RNAS during torpor when body temperature is $5-6^{\circ} \mathrm{C}$, is surprisingly high rang- ing from 5 to $25 \%$ of cenothermic levels depending upon organ (Table 2). It is not known if RNAS occurs at a constant rate for the duration of the torpor. However should this occur, then the amount of RNAS measured during the $33 \mathrm{~h}$ of torpor could be doubled to facilitate a comparison between synthesis during torpor and CEN based upon equal whole body metabolic expenditure. The amount of synthesis during torpor then becomes quite remarkable. Irrespective of a metabolically based adjustment of synthesis, the results clearly demonstrate that the processes involved in uridine incorporation into total RNA, such as transport by the energy dependent concentrative and equilibrative nucleoside transporters [35], enzymatic phosphorylation and ultimately incorporation into RNA [28] are only modestly inhibited by thermodynamic factors during torpor.

In each organ, with the exception of heart and kidney tissue, the amount of $\left[{ }^{3} \mathrm{H}\right]$-uridine incorporated into total RNA during torpor is proportional to the incorporation during CEN (Fig. 2). As with the inhibition of PS, this suggests the existence of regulatory mechanisms common to all tissues, except kidney and heart, the activity of which is carried over from CEN to torpor. Speculatively, this may involve reduction of the rates of initiation and/or elongation of total RNA, analogous to the mechanisms that depress protein synthesis [12] and reduce rates of initiation of mRNA transcription [36]. Relative to CEN, regional blood flow to the heart is proportionally greater during torpor [37], and thus the higher rates of $\left[{ }^{3} \mathrm{H}\right]$-uridine incorporation into heart, and possibly kidney, may be influenced by relative increase in substrate availability.

Although technical differences between in vivo studies make comparisons of the magnitude of incorporation of label into RNA difficult in these three families of hibernators, each study clearly demonstrates transcription of total RNA during torpor. Collectively these results imply active synthesis and degradation of total RNA during torpor in light of the finding that total RNA content of peripheral tissues is unchanged or slightly increased in brain tissue during torpor relative to CEN. In contrast, mRNA appears not to be synthesized or degraded during torpor.

Labeled RNA from heart and brain tissues, considered the most atypical and typical tissues respectively, were chosen for purification and analysis of incorporation of $\left[{ }^{3} \mathrm{H}\right]$-uridine into mRNA. The profile of radioactive incorporation into pre-mRNA and mature mRNA, as determined by oligo-poly dT chromatographic purification and scintillation counting, appears consistent for both heart and midbrain/brainstem across 
Table 3. Incorporation of $\left[{ }^{3} \mathrm{H}\right]$-uridine in RNA and mRNA in heart and brain tissue during phases of the hibernation cycle.

\begin{tabular}{|c|c|c|c|}
\hline & $\begin{array}{l}\mu \mathrm{g} \text { RNA/mg tissue }(n) \\
\mu \mathrm{g} \text { mRNA/ } \mu \mathrm{g} \text { RNA }(n)\end{array}$ & $\begin{array}{c}\text { Heart } \\
0.94 \pm 0.03(10) \\
0.022 \pm 0.001(10)\end{array}$ & $\begin{array}{c}\text { Brain stem/midbrain } \\
\begin{array}{c}0.59 \pm 0.06(10) \\
0.048 \pm 0.005(10)\end{array}\end{array}$ \\
\hline $\begin{array}{l}\text { CEN } \\
(n=4)\end{array}$ & $\begin{array}{c}{\left[{ }^{3} \mathrm{H}\right] \mathrm{cts} / \mu \mathrm{g} \text { total RNA }} \\
\text { Percent CEN RNA } \\
{\left[{ }^{3} \mathrm{H}\right] \text { cts/ } / \mu \mathbf{g} \text { mRNA }} \\
\text { Percent CEN mRNA }\end{array}$ & $\begin{array}{c}11.8 \pm 2.7 \\
[100 \pm 23 \%)] \\
\mathbf{1 0 5 . 9} \pm \mathbf{1 6} \\
{[\mathbf{1 0 0} \pm \mathbf{1 5 \%}]}\end{array}$ & $\begin{array}{c}2.2 \pm 0.6 \\
{[100 \pm 26 \%]} \\
\mathbf{1 2 . 1} \pm \mathbf{2 . 0} \\
{[\mathbf{1 0 0} \pm \mathbf{1 6 \%}]}\end{array}$ \\
\hline $\begin{array}{l}\text { Middle } \\
\text { Arousal } \\
\text { Phase } \\
(n=3) \\
\text { Torpor } \\
(n=3)\end{array}$ & $\begin{array}{c}{\left[{ }^{3} \mathrm{H}\right] \mathrm{cts} / \mu \mathrm{g} \text { total RNA }} \\
\text { Percent CEN RNA } \\
{\left[{ }^{3} \mathrm{H}\right] \text { cts/ } / \mu \text { g mRNA }} \\
\text { Percent CEN mRNA } \\
{\left[{ }^{3} \mathrm{H}\right] \mathrm{cts} / \mu \mathrm{g} \text { total RNA }} \\
\text { Percent CEN RNA } \\
{\left[{ }^{3} \mathrm{H}\right] \mathrm{cts} / \mu \mathrm{g} \text { mRNA }} \\
\text { Percent CEN mRNA }\end{array}$ & $\begin{array}{c}16.4 \pm 11.8 \\
{[139 \pm 100 \%]} \\
\mathbf{1 3 2 . 9} \pm \mathbf{9 6 . 6} \\
{[\mathbf{1 2 6} \pm \mathbf{9 1 \%} \%} \\
2.7 \pm 0.2 \\
{[23 \pm 2 \%]} \\
\mathbf{1 1 . 2} \pm \mathbf{3 . 8} \\
{[\mathbf{1 1} \pm \mathbf{4 \%} \%}\end{array}$ & $\begin{array}{c}1.3 \pm 0.8 \\
{[58 \pm 35 \%]} \\
4.2 \pm 3.6 \\
{[35 \pm 29 \%]} \\
0.9 \pm 0.1 \\
{[40 \pm 5 \%]} \\
1.4 \pm 0.1 \\
{[11 \pm 1 \%]}\end{array}$ \\
\hline
\end{tabular}

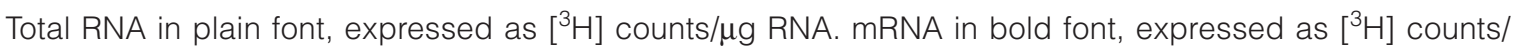
$\mu \mathrm{g}$ RNA. \% of CEN RNA - mean incorporation into tissue during phase of hibernation expressed as [\%] of mean incorporation of same tissue during CEN.

the phases of the hibernation cycle. $\left[{ }^{3} \mathrm{H}\right]$-uridine is preferentially incorporated into mRNA in CEN and more variably incorporated in the middle arousal phase. In contrast to the significant incorporation into total RNA during torpor, incorporation of labeled uridine into mRNA during torpor was low in both tissues, and close to the limit of purity that can be achieved by the chromatographic procedure. This lack of in vivo synthesis of mRNA, is consistent with the near cessation of mRNA synthesis predicted on the basis of reduced mRNA elongation rates from nuclear run on assays performed at the low temperatures approximating torpor in liver tissue [36]. Thus in the brain and heart (this experiment) and liver [36], mRNA appears not to be preferentially synthesized or degraded [24] during torpor.

The oxygen consumption during in vivo incubations of torpor and early arousal was estimated to be 50 and $40 \%$, of the CEN incubation period, respectively. However, the characteristics of PS and RNAS in the early arousal phase were distinct from those during torpor. In the early arousal phase, both PS and RNAS were arrested, and below the detectable limit in the majority of organs, despite a substantial increase in MR and temperature via non-shivering thermogenesis. The inhibition of mRNA synthesis in vivo during torpor and early arousal is in contrast to a number of previous studies reporting increased levels of cDNA probed mRNA in tissues from animals sampled across the hibernation cycle. As stated previously the preservative character of hibernation determines that this technique is not temporally specific and suggests that some previous studies should be re-assessed with a more exacting emphasis on distinguishing between molecular events preparatory for the onset of torpor and the events occurring during torpor.

Plasma concentrations of labeled precursors indicated that transport of $\left[{ }^{14} \mathrm{C}\right]$-leucine, but not $\left[{ }^{3} \mathrm{H}\right]$ uridine or labeled metabolites, from the circulation appears reduced during the early arousal phase. Intriguingly, leucine exchangers functioned earlier at colder body temperatures during torpor (from $20 \mathrm{~h}$ up until $50 \mathrm{~h}$ ) despite very little PS and also later in the middle arousal phase when tissue temperature and MR further increased and PS was re-initiated. It is not known if the absence of PS during early arousal or some aspect of physiology specific to early arousal, such as an increase in whole body $\mathrm{pH}$ via respiratory alkalosis, a putative prerequisite for reversal of metabolic inhibition and initiation of arousal [1], alters the intracellular environment such that an appropriate ligand for the system L amino acid exchangers [38] becomes less available and transport of $\left[{ }^{14} \mathrm{C}\right]$-leucine is reduced.

It is clear that the middle arousal is the most energetically demanding phase of the hibernation cycle [3, 26]. Low plasma concentrations of labeled precursors and metabolites indicate a high rate of trans-membrane transport. PS, RNAS and mRNA synthesis during the middle arousal phase were significantly elevated, somewhat heterogeneous between animals in respect to RNA and mRNA synthesis, and strongly 
influenced by tissue temperature. FeM tissue and RhB tissue are both skeletal muscles but the latter underlies BAT and is warmed much earlier than the former during arousal. PS and RNAS during middle arousal phase remained undetectable in the colder FeM while synthesis approached half CEN levels in the warmer RhM. These results complement previous polysomal run on analysis in liver [12] and provide in vivo evidence to support the finding that the mechanisms depressing both PS and RNAS, in all body tissues, requires a temperature threshold of about $18^{\circ} \mathrm{C}$ to be surpassed before synthesis can be re-established.

The magnitude of PS during the middle arousal was tissue specific. Relative to CEN levels, PS in brain tissue, particularly midbrain/brainstem and cerebellum during middle arousal, is greater than in other organs assayed despite modest increases in RNAS and lower tissue temperature than during CEN. The high level of PS in these brain structures may be indicative of a need for PS to replace the proteins utilized in the coordination of torpor and the early arousal phase. In vivo PS and RNAS and mRNA synthesis during the middle arousal phase is consistent with previous experiments where tissues from animals killed in the middle arousal to late arousal phase showed increased expression of brain tissue levels of transcription factors $[16,19]$, glucose regulating proteins and messenger proteins JNK, Akt and PKC [39] and UCP mRNA [20] relative to pre aroused animals.

In conclusion, the results of this study in hamsters show that significant gene expression occurs during the middle to late arousal phase of the hibernation cycle in organs that have surpassed a temperature threshold. In contrast, the initiation of arousal from torpor and the warming of anterior organs during early arousal by non-shivering thermogenesis occurred without measurable transcription or translation. During torpor, low levels of PS occurred in all organs. The brains of torpid animals have a slightly higher content of RNA (RNA/wet weight) than cold adapted non-hibernation hamsters. Significant amounts of total RNA are synthesized during torpor at tissue specific levels often related to the level of synthesis during CEN. The function of this RNA is unknown. If brain, heart and liver tissues are indicative of other organs, it is unlikely that functional levels of mRNA are synthesized during torpor. The low level of PS and mRNA synthesis during torpor and early arousal suggest that the majority of molecular processing required for the induction of hibernation and the arousal from hibernation up until the onset of shivering thermogenesis occurs during the cenothermic period before the hamster initiates the hibernation cycle.
This work was funded by JSPS Grant-in-Aid for Scientific Research (B) \# 14370018 and 16390057 to $\mathrm{MH}$ and an International Fellowship grant to PGO from the Takeda Science Foundation.

\section{REFERENCES}

1. Malan $\mathrm{A}: \mathrm{pH}$ as a control factor in hibernation. In: Living in the Cold. Physiological and Biochemical Adaptations, ed. Heller HC, Musacchia XJ, and Wang LC, Elsevier, New York, pp 61-70, 1986

2. Snapp BD, and Heller HK: Suppression of metabolism during hibernation in ground squirrels (Citellus lateralis). Physiol Zoo 54: 297-307, 1981

3. Wang LC: Energetic and field aspects of mammalian torpor: The Richardson's ground squirrel. In: Strategies in cold: Natural torpidity and thermogenesis, ed. Wang LC and Hudson JW, Academic Press, New York, pp 109-145, 1978

4. International Union of Physiological Sciences. IUPS Thermal Commission: Glossary of terms for thermal physiology. Jpn J Physiol 51: 245-280, 2001

5. Hashimoto M, Goa B, Kikuchi-Utsumi K, Ohinata H, and Osborne PG: Arousal from hibernation and BAT thermogenesis against cold: central mechanisms and molecular basis. J Therm Biol 27: 503-515, 2002

6. Bocharova LS, Gordon R, and Arkhipov VI: Uridine uptake and RNA synthesis in the brain of torpid and awakened ground squirrels. Comp Biochem Physiol B 101: 189-192, 1992

7. Satake M, Matsukawa S, and Miyazawa N: Rapidly labeled RNA in the hibernating bat brain. Nature. 218: 768-769, 1968

8. Whitten B, and Klain G: Protein metabolism in hepatic tissue of hibernating and arousing ground squirrels. Am J Physiol 214: R1360-R1362, 1968

9. Zhegunov GF, Mukulinsky YE, and Kudokotseva EV: Hyperactivation of protein synthesis in tissues of hibernating animals on arousal. Cryo-Letters 9: 236-245, 1988

10. Frerichs KU, Smith CB, Brenner M, DeGracia DJ, Krause GS, Marrone L, Dever TE, and Hallenbeck JM: Suppression of protein synthesis in brain during hibernation involves inhibition of protein initiation and elongation. Proc Nat Acad Sci USA 95: 14511-14516, 1998

11. Chen Y, Matsushita M, Nairn AC, Damuni Z, Cai D, Frerichs KU, and Hallenbeck JM: Mechanisms for increased levels of phosphorylation of elongation factor 2 during hibernation in ground squirrels. Biochem 40: 11565-11570, 2001

12. van Breukelen F, and Martin SL: Translational initiation is uncoupled from elongation at $18^{\circ} \mathrm{C}$ during mammalian hibernation. Am J Physiol 281: R1374-R1379, 2001

13. Hittel D, and Storey KB: The translation state of differentially expressed mRNAs in hibernating 13-lined ground squirrel (Spermophilus tridecemlineatus). Arch Biochem Biophys 401: 244-254, 2002

14. Soukri A, Valverde F, Hafid N, Elkebbaj M, and Serrano A: Occurrence of a differential expression of the glyceraldehyde-3-phophate dehydrogenase gene in muscle and liver from euthermic and induced hibernating jerboa (Jaculus orientalis). Gene 181: 139-145, 1996 
15. Andrews MT, Squire TL, Bowen CM, and Rollins MB: Low temperature carbon utilisation is regulated by novel gene activity in heart of a hibernating mammal. Proc Natl Acad Sci USA 95: 8392-8397, 1998

16. Bitting L, Sutin EL, Watson FL, Leard LE, O'Hara CF, Heller HC, and Kilduff TS: C-fos mRNA increases in ground squirrel suprachiasmatic nucleus during arousal from hibernation. Neurosci Lett 165: 117-21, 1994

17. Boyer BB, Barnes BM, Lowell BB, and Grujic D: Differential regulation of uncoupling protein gene homologues in multiply tissues of hibernating ground squirrels. Am J Physiol 275: R1232-R1238, 1998

18. Liu XT, Lin QS, Li QF, Huang CX, and Sun RY: Uncoupling protein mRNA, mitochondrial GTP-binding, and T4 5'-deiodinase activity of brown adipose tissue in Durian ground squirrel during hibernation and arousal. Comp Biochem Physiol A 120: 745-752, 1998

19. O'Hara BF, Watson FL, Srere HK, Kumar H, Wiler SW, Welch SK, Bitting L, Heller HC, and Kilduff TS: Gene expression in the brain across the hibernation cycle. J Neurosci 19: 3781-3790, 1999

20. Srere, HK, Wang LC, and Martin SL: Central role for differential gene expression in mammalian hibernation. Proc Nat Acad Sci USA 89: 7119-7123, 1992

21. Yu EZ, Hallenbeck JM, Cai D, and McCarron M: Elevated arylalkylamine-N-acetyltransferase (AA-NAT) gene expression in medial habenular and suprachiasmatic nuclei of hibernating ground squirrels. Mol. Brain Res 102: 9-17, 2002

22. Bauer VW, Squire TL, Lowe ME, and Andrews MT: Expression of a chimeric retroviral-lipase mRNA confers enhanced lipolysis in a hibernating mammal. Am J Physiol 281: R1186-R1192, 2001

23. Carey HV, and Martin SL: Preservation of intestinal gene expression during hibernation. AmJ Physiol 271: G804G813, 1996

24. Knight JE, Narus EN, Martin SL, Jacobson A, Barnes $\mathrm{BM}$, and Boyer BB. mRNA stability and polysome loss in hibernating arctic ground squirrels (Spermophilus parryii). Mol Cell Biol 20: 6374-6379, 2000

25. van Breukelen F, and Carey HV: Ubiquitin conjugate dynamics in the gut and liver of hibernating ground squirrels. JComp Physiol B 172: 269-273, 2002

26. Osborne PG, and Hashimoto M: State dependent regulation of cortical blood flow and respiration in ham- sters: response to hypercapnia during arousal from hibernation. J Physiol 547: 963-968, 2003

27. Hogans AF, Guroff $G$, and Udenfriend S: Studies on the origin of pyrimidines for biosynthesis of neural RNA in the rat. J Neurochem 18: 1699-1710, 1971

28. Traut TW, and Jones ME: Uracil metabolism, UMP synthesis from orotic acid or uridine and conversion of uracil to B-alanine. Prog Nuc Acids Res Mol Biol 53: 178, 1996

29. Heller HC, and Colliver GW: CNS regulation of body temperature during hibernation. Am J Physiol 227: 583589, 1974

30. Lyman CP, and O'Brien RC: Sensitivity to low temperature in hibernating rodents. Am J Physiol 222: 864-869, 1972

31. Chatfield PO, and Lyman CP: Circulatory changes during the process of arousal in the hibernating hamster. Am J Physiol 163: 566-574, 1950

32. Daan S, Barnes BM, and Strijkstra AM: Warming up for sleep ? - ground squirrels sleep during arousals from hibernation. Neurosci Lett 128: 265-268, 1991

33. Saborio JL, and Aleman V: Study of RNA in subcellular fractions from rat brain: simultaneous incorparation of $\left[{ }^{14} \mathrm{C}\right]$ uridine and $\left[{ }^{3} \mathrm{H}\right]$ methyl-I-methionine. J Neurochem 17: 91-101, 1970

34. Sun Y, Deibler GE, Sokoloff L, and Smith CB: Determination of regional rates of cerebral protein synthesis adjusted for regional differences in recycling of leucine derived from protein degradation into the precursor pool in conscious adult rats. J Neurochem 59: 863-873, 1992

35. Cabrita MA, Baldwin SA, Young JD, and Cass CE: Molecular biology and regulation of nucleoside and nucleobase transporter proteins in eukaryotes and prokaryotes. Biochem Cell Biol 80: 623-638, 2002

36. van Breukelen F, and Martin SL: Reversible depression of transcription during hibernation. J Comp Physiol B 172: 355-361, 2002

37. Wells AL: Circulatory patterns in hibernators. Am J Physiol 221: 1517-1520, 1971

38. Verrey F: System L: heteromeric exchangers of large neutral amino acids involved in directional transport. Eur J Physiol 445: 529-533, 2003

39. Lee M, Choi I, and Park K: Activation of stress signaling molecules in bat brain during arousal from hibernation. J Neurochem 82: 867-873, 2002 